\title{
Meaning in Life and Personality Traits in Adult Alcoholics
}

\author{
Jelena Bupić ${ }^{1}$, Anamarija Bogović Dijaković ${ }^{2}$ \\ ${ }^{1}$ Department of Psychiatry, General Hospital Dubrovnik, Dubrovnik, Croatia, ${ }^{2}$ Catholic \\ University of Croatia, Zagreb, Croatia; Department of Psychiatry, University Hospital Cen- \\ ter Sestre milosrdnice, Zagreb, Croatia
}

\begin{abstract}
The study explores the concept of meaning in life among adult alcoholics and individuals from the general population, as well as its relationship with personality traits based on the Big Five model. Clinical and non-clinical samples have been compared to the construct of meaning in life. After examining the relationship between meaning in life and personality traits, we analyzed the contribution of personality traits in explaining the meaning in life for both groups. The clinical sample consisted of 76 treated alcoholics from the alcoholism ward of a psychiatric hospital in Zagreb, while the non-clinical sample consisted of 77 participants. The following questionnaires were applied: Purpose in Life Test, IPIP - 100, and a questionnaire on general data created exclusively for the purpose of this research. The results have shown significant differences in experience regarding meaning in life between the clinical and non-clinical sample, as individuals from the general population consider their life to be more meaningful. Furthermore, meaning in life had a significant positive relationship to extraversion, agreeableness, openness and conscientiousness and significant negative to neuroticism, in both groups. Extraversion and conscientiousness in the explanation of meaning in life were significant predictors in the general population, while extraversion and neuroticism were significant predictors among adult alcoholics, with neuroticism as a negative predictor. The results of this study, apart from new scientific findings, could contribute to the development of practical interventions and improvements in the treatment of persons with alcohol addiction.
\end{abstract}

Key words: meaning in life, alcoholism, addiction, alcohol addicts, personality traits, Big Five model

Copyright @ 2019 KBCSM, Zagreb

e-mail: alcoholism.kbcsm@gmail.com•www.http://apr.kbcsm.hr

\section{Introduction}

The subject of meaning in life is as old as mankind. Probably every human being has wondered at least once about his or her pur-

Correspondence to: Jelena Bupić, Department of Psychiatry, General Hospital Dubrovnik, Dr. Roka Mišetića 2, 20000 Dubrovnik, Croatia

E-mail: bupic.jelena@gmail.com pose or meaning in life. According to Frankl [1], the meaning in life is impossible to universally define, because it differs from one person to another, from one situation to another, and may be different at each stage of life. According to Reker and Wong, as cited by Zika and Chamberlain [2], the meaning in life is defined as a cognizance of harmony, order and purpose in an individual's existence, alongside the 
strive for reaching goals that seem to be worth the effort, realization of the goals and an accompanying sense of fulfillment.

Meaning in life has been linked to numerous psychological constructs and outcomes. Firstly, lack of meaning was associated with psychopathology, but also a very important determining factor of psychological well-being [2]. Results of previous studies suggest that meaning in life is a clinically relevant construct, distinguishing patient from nonpatient population, it has a predictive power and plays an important role in general mental health of an individual [3,4].

The most famous researcher in this area is certainly Viktor Frankl, who is also the founder of logotherapy, the psychotherapy focused on the meaning in life. According to him [1], humans are primarily motivated by the will to meaning, which means that meaning is our primary motivation for living and acting. When the will to meaning is interrupted or blocked, existential frustration may appear, surrounding the individual with a general sense of meaninglessness, demonstrated as a state of apathy or boredom [1]. Furthermore, meaninglessness or existential vacuum is a phenomenon accompanied by feelings that life has no purpose. These feelings lead to the mass neurotic triad or, in other words, to the development of depression, aggression and addiction; and alcoholism is considered as a form of an addiction [5]. Moreover, each person alone has to discover the meaning for him or herself, and meaning can be discovered in three ways: through actions (creative values), through connections (experiential values), through suffering (attitudinal values) $[1,5]$. In the end, in responsibility Frankl sees the essence of existence itself [1].

According to Yalom [6], several secular activities offer a sense of meaning in life to a person: altruism, dedication to a cause (the family, the state, a political or religious cause, a scientific venture), creativity, hedonism, self - actualization and self - transcendence. However, it is very important that individuals are dedicated to their chosen meanings [6]. Each individual is responsible for himself for who he is and what he becomes [7]. According to Maslow, as cited by Debats [4], meaning in life is a meta - need, and gratification of this need creates growth, but meaning in life as a meta - need has no impact on human motivation until the lower needs are satisfied.

Alcohol addiction is defined as "a progressive fatal disease characterized by loss of the ability to control drinking alcohol, obsession with alcohol, denial of relationship between drinking alcohol and deterioration of health and life opportunities"[8]. Considering that drinking alcoholic beverages is socially acceptable, it is no surprise that alcohol abuse disorder is the third public health problem [9]. According to data from 2010, 5.6\% of the population in the Republic of Croatia suffers from alcohol abuse disorders [10].

The development of substance abuse and the experience of meaninglessness in life have been linked in a number of previous studies [11]. As mentioned above, lack of meaning leads to development of alcohol dependence [5]. The meaning in life construct may have an important role in sustaining abstinence from drinking in AA [12]. Furthermore, the results from previous studies suggest a negative relationship between the meaning in life and alcohol use among college students, i.e. the meaning in life is shown to be a significant predictor in the explanation of alcohol drinking [13,14]. Another study showed a positive relationship between the experience of meaning in life and the extent of practice of Alcoholics Anonymous Step 11 [15]. 
There is clear evidence suggesting that the non-alcoholic population experiences their life to be more meaningful than alcohol addicts $[11,16]$.

People differ in many ways. Hence, they may differ in experiencing meaning in life. This realization leads us to question how some personal characteristics, especially the widely studied and well-validated Big Five personality traits, are associated with the perception of meaning in life and how they contribute to the explanation of meaning in life. According to Costa and McCrae, as cited by John, Pervin and Cervone [17] the Big Five model consists of neuroticism, extraversion, openness, agreeableness and conscientiousness.

Neuroticism indicates a tendency toward unstable emotions and identifies individuals inclined to maladjusted coping responses, enormous cravings, unreal ideas and psychological distress [17]. Previous studies have revealed a negative relationship between neuroticism and the experience of meaning in life, both in university students and older population [18]. These correlations are evident in both male and female outpatients with mixed diagnoses [19]. Moreover, neuroticism was found to be a negative predictor in the explanation of meaning in life $[20,21]$.

Extraversion signifies quantity and intensity of social interaction, need for stimulation, activity level and capacity for satisfaction [17]. Even though extraversion and meaning in life showed a consistent positive association, the same studies have also shown that extraversion is an inconsistent predictor in the explanation of meaning in life $[20,21]$. On the other side, some studies have been shown a positive relationship between these two constructs, both in university students and older population [18] and both for male and female outpatients with mixed diagnoses [19].

Openness evaluates proactive seeking and appreciation of experience for its own purpose, tolerance and examination of the unknown [17]. According to Isik and Uzbe [21], openness has a positive relationship with meaning in life and contributes to the explanation of meaning in life as a positive predictor. In other studies, openness is not related to meaning in life at all $[22,23]$, while in another study it relates to meaning in life only among university students [18]. Despite those contradictions, the relationship between the sense of meaning in life and openness is still not well clarified.

Conscientiousness measures the individual's degree of organization, perseverance and motivation in the aim-directed behavior [17]. Reviewing the relevant literature, it seems that conscientiousness is consistently positively correlated with the sense of meaning in life $[21,22,18]$. Therefore, it seems that the results are consistent.

The last of the Big Five model personality traits is agreeableness. Agreeableness refers to the quality of individuals' social orientation, from empathy to animosity in thoughts, feelings and actions [17]. While some studies show a positive relationship [21, 22], other studies show a negative relationship between meaning in life and agreeableness [18].

Considering that meaning in life is a relevant clinical construct, its underrepresentation in psychological research, especially in Croatia, was our primary motive for conducting this research. Moreover, such research was necessary as the authors have noticed a lack of studies exploring the relationship between the meaning in life and personality traits worldwide. The practical implications 
of this study could be helpful to experts in their work with alcohol addicts, as well as in their work with individuals from the general population.

The first aim of this study was to investigate whether there was a difference in experience of meaning in life between the two groups, alcoholics and individuals from the general population. The second aim was to examine the relationship between the sense of meaning in life and personality traits as expressed in the Big Five model, for both groups. The third and final aim of the study was to investigate how much variance of life meaningfulness can be explained by personality traits as expressed in the Big Five model, also for both groups.

\section{Method}

\section{Subjects}

The clinical sample included 76 voluntary inpatients who were treated for alcohol addiction in a psychiatric hospital in Zagreb, of which 65 were male and 11 were female. Participants were divided into two groups according to their age range: early middle-age (30$49 ; n=41)$ and late middle-age (50-67; $n=35)$. Participants in the clinical sample mostly had high school education and were not working, they were either unemployed or pensioners. The majority of the sample were married or in a relationship. The non-clinical sample included 77 voluntary individuals from the general population, of which 34 were male and 43 were female. Participants were also divided into the same two age groups: early middle-age (30-49; $\mathrm{n}=54)$ and late middle-age (50-67; $n=23)$. Participants in the non-clinical sample mostly had completed high school education and were employed. The major- ity of the sample was married. Convenient and intentional sampling method was used to recruit the participants in this study.

\section{Measures}

Three sets of measures were utilized.

A questionnaire especially constructed for this study was used for collecting sociodemographic data.

\section{Meaning in life}

The Purpose in Life Test was used to assess the meaning in life in this study. It is a questionnaire specially designed to measure the extent to which a respondent perceives a general sense of meaning in life or suffers from an existential vacuum [3]. The test was validated and translated into Croatian [24] and consists of 23 items, each measured on a 5 - point Likert - type scale (1 - It does not apply to me at all to 5-It does apply to me at all). In previous studies Cronbach's Alpha for this scale was 0.89 [24], while in this study it was 0.89 for both samples.

\section{Personality traits}

In this study, personality traits were assessed with the International Personality Item Pool - 100 questionnaire [25], which was validated and translated into Croatian [26]. The questionnaire consists of 100 short items (20 for every dimension) and measures five major personality traits as defined in the Five-factor theory, namely neuroticism, extraversion, openness, agreeableness and conscientiousness. This instrument utilizes a 5 - point Likert - type scale (1 - very inaccurate to 5 - very accurate) and yields 5 scale scores, each for every personality trait. Participants were asked to indicate their amount of agreement with each item. In previous studies 
Table 1. Descriptive statistics of used variables for the clinical and non-clinical sample.

\begin{tabular}{lcccccc}
\hline & \multicolumn{2}{c}{ Clinical sample } & & \multicolumn{2}{c}{ Non-clinical sample $^{\mathrm{b}}$} \\
\cline { 2 - 3 } \cline { 5 - 6 } & $\mathrm{M}$ & $\mathrm{SD}$ & & $\mathrm{M}$ & $\mathrm{SD}$ \\
\hline Meaning in life & 83.99 & 13.533 & & 95.29 & 10.076 \\
Neuroticism & 60.26 & 12.628 & & 54.77 & 13.368 \\
Extraversion & 67.42 & 12.272 & & 69.63 & 10.201 \\
Openness & 72.46 & 10.572 & & 68.06 & 10.270 \\
Agreeableness & 73.79 & 8.965 & & 74.14 & 8.699 \\
Conscientiousness & 75.08 & 12.290 & & 76.13 & 10.518 \\
\hline
\end{tabular}

Note: ${ }^{\mathrm{a}} \mathrm{N}=76 ;{ }^{\mathrm{b}} \mathrm{N}=77$

Cronbach's Alpha for neuroticism was 0.92, for extraversion 0.93 , for openness 0.87 , for agreeableness 0.87 and for conscientiousness 0.92 [26]. In this study psychometric analyses revealed the following Cronbach's Alpha. Clinical sample: neuroticism was 0.87 , for extraversion 0.87 , for openness 0.82 , for agreeableness 0.77 and for conscientiousness 0.87. Non-clinical sample: neuroticism 0.86, for extraversion 0.88 , for openness 0.85 , for agreeableness 0.69 and for conscientiousness 0.89 .

\section{Procedure}

The study was conducted in accordance with the ethical standards and approval of the Ethics Committee of a psychiatric hospital in Zagreb. All the participants signed the informed consent form. Anonymity of data was guaranteed and the results of the study were used only for scientific purposes.

\section{Results}

The descriptive and statistical analysis was conducted using the IBM SPSS program, version 21.

Descriptive statistics of the following variables: meaning in life, neuroticism, extraversion, openness, agreeableness and conscientiousness, for the clinical and non-clinical sample are presented in Table 1. The average score for the non-clinical sample group on the scale which estimates the meaning in life was 95.29 ( $\mathrm{SD}=10.076)$, while the average score for the clinical sample group was 83.99 ( $\mathrm{SD}=13.533$ ). In order to test whether the sense of meaning in life differed among the groups included in the study, the Students

Table 2. Students' t-test between the clinical and non-clinical sample.

\begin{tabular}{lccc}
\hline & $t$ & $d f$ & Sig (2-tailed) \\
\hline Meaning in life & -5.931 & 142 & 0.00 \\
\hline
\end{tabular}


Table 3. Intercorrelations among all variables for the clinical and non-clinical sample.

\begin{tabular}{lcccccc}
\hline & 1. & 2. & 3. & 4. & 5. & 6. \\
\hline 1. Meaning in life & - & $-0.59^{* *}$ & $0.67^{* *}$ & $0.28^{* *}$ & $0.39^{* *}$ & $0.56^{* *}$ \\
2. Neuroticism & $-0.30^{* *}$ & - & $-0.29^{* *}$ & 0.10 & -0.03 & $-0.39^{* *}$ \\
3. Extraversion & $0.54^{* *}$ & $-0.22^{*}$ & - & $0.34^{* *}$ & $0.44^{* *}$ & $0.38^{* *}$ \\
4. Openness & $0.44^{* *}$ & 0.01 & $0.58^{* *}$ & - & $0.50^{* *}$ & $0.46^{* *}$ \\
5. Agreeableness & $0.48^{* *}$ & $-0.35^{* *}$ & $0.58^{* *}$ & $0.40^{* *}$ & - & $0.62^{* *}$ \\
6. Conscientiousness & $0.49^{* *}$ & -0.16 & $0.31^{* *}$ & $0.36^{* *}$ & $0.35^{* *}$ & - \\
\hline
\end{tabular}

Note: ${ }^{*} \mathrm{p}<.01 ;{ }^{*} \mathrm{p}<.05$; Correlations for the clinical sample are shown above the diagonal; correlations for the non-clinical sample are shown under the diagonal.

t-test for large independent samples was run, and the results are presented in Table 2. Alcohol addicts reported a significantly lower sense of meaning in life than individuals from the general population $\left(\mathrm{t}_{(142)}=-5.931\right.$, $\mathrm{p}<.01)$.

Pearson Product-Moment correlation was used to determine the relationship between the sense of meaning in life and personality traits for both groups in the study. Table 3 shows the correlations among the variables. As seen in Table 3, a significant positive correlation was found between the meaning in life and extraversion $(\mathrm{r}=.67, \mathrm{p}<.01)$, as well as openness $(r=.28, \mathrm{p}<.01)$, agreeableness $(\mathrm{r}=.39, \mathrm{p}<.01)$ and conscientiousness $(\mathrm{r}=.56$, $\mathrm{p}<.01)$ in the clinical sample. A significant negative correlation was found between the meaning in life and neuroticism ( $\mathrm{r}=-.59$, $\mathrm{p}<.01)$ in the same sample.

In the non-clinical sample a significant positive correlation was also found between the meaning in life and extraversion $(\mathrm{r}=.54$, $\mathrm{p}<.01)$, openness $(\mathrm{r}=.44, \mathrm{p}<.01)$, agreeableness $(r=.48, \mathrm{p}<.01)$, conscientiousness $(\mathrm{r}=.49, \mathrm{p}<.01)$ and a significant negative correlation between the meaning in life and neuroticism $(\mathrm{r}=-.30, \mathrm{p}<.01)$.

In order to determine to what extent the personality traits were significant predictors of meaning in life, two separate multiple regression analysis were performed, the first for the clinical and the second for the nonclinical sample. All the obtained results are shown in Table 4.

First multiple regression analysis was used to test if the personality traits significantly predicted the participants' meaning in life in the clinical sample. The results of regression indicated that neuroticism, extraversion, openness, agreeableness and consciousness significantly explained $66.7 \%$ variance of the meaning in life $\left(\mathrm{R}^{2}=.667, \mathrm{~F}_{(5,70)=} 28.087\right.$; $\mathrm{p}<.01)$. Furthermore, neuroticism $(\beta=-.396$, $\mathrm{p}<.01)$ proved to be a negative significant predictor, while extraversion $(\beta=.441, \mathrm{p}<.01)$ proved to be a positive significant predictor.

The second multiple regression analysis indicated that the same personality traits, i. e. neuroticism, extraversion, openness, agree- 
Table 4. Summary of multiple regression analysis with meaning in life as a criterion variable for the clinical and non-clinical sample.

\begin{tabular}{|c|c|c|c|c|}
\hline \multirow[b]{2}{*}{ Predictors } & \multicolumn{2}{|c|}{ Clinical sample $^{a}$} & \multicolumn{2}{|c|}{ Non-clinical sample ${ }^{\mathrm{b}}$} \\
\hline & $\beta$ & $t$ & $\beta$ & $t$ \\
\hline Neuroticism & -0.396 & $-4.574 * *$ & -0.158 & -1.635 \\
\hline Extraversion & 0.441 & $5.337 * *$ & 0.272 & $2.215^{*}$ \\
\hline Openness & 0.064 & 0.732 & 0.137 & 1.208 \\
\hline Agreeableness & 0.037 & 0.370 & 0.112 & 0.966 \\
\hline \multirow[t]{4}{*}{ Conscientiousness } & 0.189 & 1.778 & 0.287 & $2.942^{* *}$ \\
\hline & \multicolumn{2}{|c|}{$R=0.817$} & \multicolumn{2}{|c|}{$R=0.669$} \\
\hline & \multicolumn{2}{|c|}{$R^{2}=0.667$} & \multicolumn{2}{|c|}{$R^{2}=0.448$} \\
\hline & \multicolumn{2}{|c|}{$F_{(5,70)}=28.087 * *$} & \multicolumn{2}{|c|}{$F_{(5,71)}=11.514^{* *}$} \\
\hline
\end{tabular}

Note. $\beta=$ standardized beta coefficient; $t=\mathrm{t}$ value; $\mathrm{R}=$ coefficient of determination; $\mathrm{R}^{2}=$ multiple coefficient of determination; $F=\mathrm{F}$ value; ${ }^{* *} \mathrm{p}<.01 ;{ }^{*} \mathrm{p}<.05$

ableness and consciousness significantly explained $44.8 \%$ variance of meaning in life $\left(\mathrm{R}^{2}=.448, \mathrm{~F}_{(5,71)}=11.514 ; \mathrm{p}<.01\right)$ in the nonclinical sample. Extraversion $(\beta=.272, \mathrm{p}<.05)$ and conscientiousness $(\beta=.287, \mathrm{p}<.01)$ proved to be positive significant predictors.

\section{Discussion and conclusions}

The first aim of the study was to investigate whether there was a difference in the experience of meaning in life between alcoholics and individuals from the general population. The results indicate that individuals from the general population consider their life to be more meaningful. This finding is in accordance with findings from previous studies $[11,13,14,16]$.

Most participants in the clinical sample were not working, while participants in the non-clinical sample were mostly employed.
According to Frankl [5], unemployed people can suffer from a lack of creative meaning, they often feel useless, and as a result they perceive their own life as meaningless. It is possible that lack of meaning among the unemployed population leads to the development of alcohol addiction [5]. The meaning in life may function as a protective factor in the use of alcohol [13], and people who perceive their life as meaningful, in addition to other protective factors, will be more inclined to avoid alcohol abuse. The meaning in life construct may have an important role for sustained abstinence in AA [12], but may also be connected to the extent of practice of $\mathrm{AA}$ Step 11 [15], so it seems that the concept of meaning in life has been neglected in therapeutic procedures for treating alcoholism.

The second aim was to examine the relationship between personality traits as ex- 
pressed in the Big Five model and the meaning in life, for both groups.

Neuroticism is negatively correlated with the meaning in life in both studied groups, which is in accordance with the previous studies [18, 19]. It seems that people with high scores on neuroticism, who are anxious, nervous and insecure [17], may have blocked their way to discover meaning in their life.

Extraversion and meaning in life show a significant positive relationship. Thus, it seems very likely that highly extraverted people also have a positive attitude towards life [18]. Considering that each person has to discover the meaning on their own [5], sociable, optimistic and warm-hearted people may have more chances and occasions to do that. Other studies have found the same results [20, 21, 22].

Based on the obtained results, there is a positive relationship between openness and the meaning in life, both for the clinical and non-clinical sample. As previously mentioned, openness evaluates proactive seeking and appreciation of experience for its own purpose [17] and considering the fact that meaning can be discovered through actions (creative values) and through connections (experiential values) [1], this relationship is understandable and justified. Creativity is also one of the activities that offer to an individual a sense of meaning in life [6] and creativity is a characteristic of individuals high on openness [17]. Those people probably have more opportunities to achieve a meaningful life.

The results of this study show a significant positive relationship between meaning and agreeableness, both for the clinical and nonclinical sample. The meaning can be discovered through connections, especially through connections with other people, loving and caring for them [1], and agreeableness defines quality of individuals' interpersonal orientation [17]. Considering these explanations, the results on the positive relationship between agreeableness and meaning in life should be observed. Moreover, this result is concordant to previous studies [21, 22].

In this study, the meaning in life significantly positively correlates to consciousness in both studied groups. This finding is supported by similar previous research studies $[18,21,22]$. As Frankl sees in responsibility the essence of existence itself [1], the existentialists consider that each individual is responsible for who he or she is [7]. Consciousness seems to be an important correlate of the meaning in life.

According to the obtained results, personality traits of extraversion and consciousness predict the meaning in life in the non-clinical sample, while personality traits of extraversion and neuroticism predict the same construct in the clinical sample.

Although previous findings have shown that extraversion is an inconsistent predictor in the explanation of meaning in life $[20,21]$, it seems that a general tendency to experience a positive affect, typical for extroverted people, may be essential in obtaining meaning in life. What is more interesting, extraversion is the only personality trait that has been revealed as a significant predictor of meaning in life in both studied groups. It is also possible that extroverted people in general participate in many activities, and consequently have many opportunities to perceive their life as meaningful.

Personality trait of conscientiousness significantly predicts the meaning in life in the non-clinical sample, and such result was not found in the relevant literature so far. However, this result is not surprising if we remember that the fundamental postulate 
of Frankl's theory lies in responsibility [1]. Personality trait of conscientiousness significantly predicts the meaning in life in the non-clinical sample, and this result has not been found in the relevant literature so far. However, the result is not surprising bearing in mind that the fundamental postulate of Frankl's theory lies on responsibility. According to this theory, each person is obligated to responsibly accept life, life's tasks, obstacles, and even suffering [1]. Also, the main objective of psychotherapy based on Frankl's theory is focused on awakening awareness about personal responsibility for one's own life [1].

Neuroticism is, based on the obtained results, a negative predictor of meaning in life among alcohol addicts. Although neuroticism negatively correlates with the meaning in life in both groups in this study, it seems that this personality trait plays a much more important role in the explanation of meaning in life in the specific group of alcohol addicts, than in the group of individuals from the general population. If we assume that alcoholics are emotionally more unstable than

\section{References}

1. Frankl VE. Man's Search for Meaning. Zagreb: Planetopija; 2010.

2. Zika S, Chamberlain K. On the relation between meaning in life and psychological well-being. $\mathrm{Br} \mathrm{J}$ Psychol. 1992;83:133-145.

3. Crumbaugh J, Maholick LT. An experimental study in existentialism: The psychometric approach to Frankl's concept of noogenic neurosis. J Clin Psychol. 1964;20:200-201.

4. Debats DLHM. Meaning in life: psychometric, clinical and phenomenological aspects (dissertation). Groningen: University of Groningen; 1996.

5. Frankl VE. The Unheard Cry for Meaning. Zagreb: Naprijed; 1981. non-alcoholics, it can easily be explained why this trait is a negative predictor of meaning in life in this group.

Limitations of this study are mostly related to the small clinical and non-clinical sample. Another lack of the study lies in the fact that the clinical sample consists mostly of men. Future studies should include more women in a clinical sample, and the sample itself should be larger. Also, when questioning whether experiencing meaning in life should be seen as a trait or state, future studies should conduct a longitudinal research on meaning. The results of this study, apart from new scientific findings, could contribute to the development of practical interventions and improvement in the treatment of people with alcohol addiction.

\section{Acknowledgements}

None.

\section{Conflict of interest}

None to declare.
6. Yalom ID. Existential psychotherapy. New York: Basic Books; 1980.

7. Yalom ID, Josselson R. Existential psychotherapy. In: D. Wedding and R. J. Corsini, ed. Current Psychotherapies. Belmont, CA: Brooks/Cole Cengage; 2014. p. 265-298.

8. Žuškin E, Jukić V, Lipozenčić J, Matošić A, Mustajbegović J, Turčić N, et al. Alcoholism - how it affects health and working capacity. Arh Hig Rada Toksikol. 2006;57:413-426.

9. Buljan D. Alcohol pharmacology and pharmacotherapy of alcoholism. Alcoholism 2011;47:5-50.

10. World Health Organization. Global status report on alcohol and health. Geneva: WHO Press; 2014.

11. Waisberg JL, Porter JE. Purpose in life and outcome of treatment for alcohol dependence. $\mathrm{Br} \mathrm{J}$ Clin Psychol. 1994;33:49-63. 
12. Oakes KE, Allen JP, Ciarrocchi JW. Spirituality, religious problem-solving, and sobriety in Alcoholics Anonymous. Alcohol Treat Q. 2000;18:37-49.

13. Wood RJ, Hebert E. The relationship between spiritual meaning and purpose and drug and alcohol use among college students. Am J Health Stud. 2005;20:72-79.

14. Schnetzer LW, Schulenberg SE, Buchanan EM. Differential associations among alcohol use, depression and perceived life meaning in male and female college students. J Subst Use. 2013;18:311-319.

15. Carroll S. Spirituality and purpose in life in alcoholism recovery. J Stud Alcohol. 1993;54:297-301.

16. Brown JM, Ashcroft FG, Miller WR. Purpose in life among alcoholics: A comparison of the three ethnic groups. Alcohol Treat Q. 1998;16:1-11.

17. John O, Pervin L, Cervone D. Personality: Theory and Research. Zagreb:Školska knjiga; 2008.

18. Halama P. Relationship between meaning in life and the big five personality traits in young adults and older. Stud Psychol (Bratisl). 2005;47:167-178.

19. Pearson PR, Sheffield BF. Purpose in life and the Eysenck Personality Inventory. J Clin Psychol 1974;30;562-564.

20. Francis LJ, Hills PR. The development of the Meaning in Life Index (MILI) and its relationship with personality and religious behaviours and beliefs among UK undergraduate students. Ment Health Relig Cult. 2008;11,211-220.

21. Isik S, Uzbe N. Personality traits and positive/negative affects: An analysis of meaning in life among adults. Educational Sciences: Theory and Practice 2015;15:587-595.

22. Steger MF, Kashdan TB, Sullivan BA, Lorentz D. Understanding the search for meaning in life: Personality, cognitive style, and the dynamic between seeking and experiencing meaning. J Pers. 2008;76:199-228.

23. Mascaro N, Rosen DH. Existential meaning's role in the enhancement of hope and prevention of depressive symptoms. J Pers. 2005;73:985-1013.

24. Vulić-Prtorić A, Bubalo J. Skala smisla života SSŽ. In: Ćubela-Adorić V, Tucak I, Proroković A, Penezić Z, eds. Zbirka psihologijskih skala i upitnika, III. Zadar: Sveučilište u Zadru; 2005. p. 49-55.

25. Goldberg LR. A broad-bandwidth, public-domain, personality inventory measuring the lower-level facets of several five-factor models. In: Mervielde I, Deary I, De Fruyt P, Ostendorf F, eds. Personality Psychology in Europe. Vol 7. Tilburg: Tilburg University Press; 1999. p. 7-28.

26. Mlačić B, Goldberg LR. An analysis of a crosscultural personality inventory: The IPIP Big-Five factor markers. J Pers Assess. 2007;88:168-177.

\section{Smisao života i osobine ličnosti u odraslih alkoholičara}

Sažetak - U radu je istraživan konstrukt smisla života ovisnika o alkoholu i osoba iz opće populacije, te njegova povezanost s osobinama ličnosti iz petofaktorskog modela. Uspoređeni su klinički i neklinički uzorak na konstruktu smisla života. Nakon ispitivanja povezanosti smisla života i osobina ličnosti iz petofaktorskog modela, ispitan je i doprinos osobina ličnosti u objašnjenju smisla života za obje skupine. Klinički uzorak činilo je 76 liječenih alkoholičara s odjela za alkoholizam jedne psihijatrijske bolnice u Zagrebu, dok se neklinički uzorak sastojao od 77 osoba iz opće populacije. Primijenjeni su upitnici Skala smisla života, Upitnik ličnosti IPIP- 100 i upitnik o općim podatcima konstruiran za potrebe ovog istraživanja. Rezultati su pokazali značajne razlike u doživljaju smisla života između kliničkog i nekliničkog uzorka, to jest osobe iz opće populacije svoj život doživljavaju smislenijim. Smisao života značajno je pozitivno povezan s ekstraverzijom, ugodnosti, otvorenosti i savjesnosti, a značajno negativno s neuroticizmom, i to kod obje skupine. Kao značajni prediktori u objašnjenju smisla života pokazali su se ekstraverzija i savjesnost kod osoba iz opće populacije, te ekstraverzija i neuroticizam kod ovisnika o alkoholu, s time da je neuroticizam imao negativni predznak. Rezultati ovog istraživanja, osim novih znanstvenih saznanja, mogli bi doprinjeti razvoju praktičnih intervencija i poboljšanju tretmana alkoholičara.

Ključne riječi: smisao života, alkoholizam, ovisnost, ovisnici o alkoholu, osobine ličnosti, petofaktorski model 